\title{
Geometry of wood screws: a patent review
}

\author{
Maciej Sydor ${ }^{1}[0$ \\ Received: 18 November 2017 / Published online: 31 October 2018 \\ (c) The Author(s) 2018
}

\begin{abstract}
The article describes the results of the review and analyses of the patent literature relating to screws for wood materials used in the furniture manufacturing and in building construction. Based on the queries performed in several databases, 611 patent families containing 1031 unique patent documents from 1902 to 2017 have been identified. These documents were analyzed, and as a result, an overview was obtained containing screw inventions that are the most influential for the present state of the art of joinery. The number of forward citations and sizes of patent families were considered in the identification of the inventions recognized as the most influential. Additionally, the oldest often-cited screw patents were also quoted. As a result, eight very significant screw inventions were identified and the types of technical issues that these inventions solve were indicated. Additionally, these results were confronted with topics taken in scientific literature. This confrontation points to the weak link between scientific literature and patent literature in the field of threaded fastener for wood materials.
\end{abstract}

\section{Introduction}

Wood and wood-based materials are produced as a technologically treated wood (such as for example solid wood, glued wood and more reconstituted products-veneers and plywood, particleboards, fiberboards-also as mixtures of substances WPC etc.). These numerous kinds of porous and fibrous engineering materials are characterized by various construction features with lack of uniformity. This is a serious challenge in joinery (Sydor 2005, 2011; Sydor and Wieloch 2009; Branowski et al. 2018). One of the most popular ways of joining elements made of wood and wood-based materials is the use of single or multi-element mechanical fasteners, especially screws. A characteristic feature distinguishing a screw from a bolt is the fact that a bolt cooperates with a previously fabricated nut, while a screw forms an internal thread in the workpiece all by itself. Often, it also bores a pilot hole.

The screws intended for wood materials have several specific construction elements, such as a screw drive to temporally attach a screwing tool, a head that limits the screw-in depth and blocks the screw in the workpiece, non-threaded shank, threaded shank forming a thread in the wood and very

Maciej Sydor

sydor@up.poznan.pl

1 Faculty of Wood Technology, Poznań University of Life Sciences, Poznań, Poland often a tip boring a pilot hole (different screw tips boring a pilot hole are shown for example in Blaß and Siebert 1999 and Pirnbacher and Schickhofer 2007). An outer layer may also be an important construction feature of screws. Apart from its main decorative and protective function, it could decrease friction torque during screwing. Screws may also be equipped with other, less common construction elements. The functions of the main structural elements of the wood screws are presented in Table 1.

The screws can be loaded axially (by pulling or pushing force) or radially (by shear force), acting in one or in many shear planes (Eurocode 5: Design of Timber Structures: Part 1-1: General-Common Rules and Rules for Buildings 2004). During screwing and unscrewing, the torque temporarily loads the screws. The screws can be a part of a multi-element fastener (Fig. 1a) or be a single or grouped fastener in the construction (Fig. 1b). The screws may also be used to attach different kinds of hardware to the surface of elements (Fig. 1c).

The oldest description and technical drawing presenting the structure and use of screws as wood fastener dates back more than 460 years (Agricola 1950). The first screws were handcrafted by a smith, and due to the high production cost, they were not widespread in technology (in the furniture industry, carpentry, or mechanical engineering). Modern screws, that is to say mass-produced cheap fasteners made through plastic processing, were developed in the middle of the 19th century (Rybczynski 2000). Despite, the seemingly 
Table 1 Components of the wood screw (on the example of a screw produced by HECO-Schrauben)

\begin{tabular}{|l|l|l|}
\hline Element of a structure & Picture & \multicolumn{1}{|c|}{ Main functions } \\
\hline Head & $\begin{array}{l}\text { Attaching and detaching a screwing tool, } \\
\text { transmission of the torque, limit of the screw-in } \\
\text { depth (especially to hold the components } \\
\text { together), and sometimes protection against } \\
\text { unscrewing or milling the edge of the hole } \\
\text { (protection against surface damage) }\end{array}$ \\
\hline Unthreaded shank & $\begin{array}{l}\text { Transmission of the axial forces, radial forces and } \\
\text { torque; prolongation of the screw }\end{array}$ \\
\hline Shank profile & & $\begin{array}{l}\text { Enlarging the diameter of the pilot hole, } \\
\text { transmission of the axial forces, radial forces, and } \\
\text { torque }\end{array}$ \\
\hline Threaded shank & $\begin{array}{l}\text { Thread burnishing in the workpiece, transmission } \\
\text { of the axial forces, radial forces, and torque }\end{array}$ \\
\hline Tip & & $\begin{array}{l}\text { Boring a pilot hole, initial cutting or burnishing of } \\
\text { the thread }\end{array}$ \\
\hline
\end{tabular}

simple construction form of the screws, new constructions are still developed in response to the various technical requirements that they must face.

The important and breakthrough inventions are usually submitted to national or international patent offices that issue so-called patents. A patent is an administrative decision made by a country or an international organization that reserves to the patent's owner a time-limited exclusive right to reap the benefits from the technical solution described in the patent application (Sydor 2017). Every patentable invention must be novel, non-obvious and useful. There are basically three types of patents: industrial designs (design patents in USA), utility models and plant patents. In the case of threaded wood fasteners, we can speak of the first two types of patents.

The Civilization Techno-Economic Network of human activity consists of six correlated poles: science pole, transfer pole, technological pole, financial pole, development pole, market pole (Bell and Callon 1994). The patent literature is an element of the technological pole. According to the Altshuller's theory (TRIZ), all innovations emerge from the application of a very small number of inventive strategies and technology evolution trends are highly predictable (Altshuller and Shapiro 1956; Terninko et al. 1998; Mann 2001). Patent literature constitutes a reliable and very organized collection of valuable technical knowledge (Abbas et al. 2014), and it can provide valuable input for support of decision on research and development strategies (Yoon et al. 2013) in particular regarding the identification of the most important technical challenges. That is why it is valuable to identify and analyze the essential patents in each domain. The purpose of this article is to indicate the most important patented inventions regarding screws for all wood materials and to identify kinds of issues that the inventors of the most innovative screws were trying to solve. This article presumes that all valuable inventions are patented.
Fig. 1 Examples of wood screws usage: a screws in a post and beam construction (source: RICON 2017), b furniture screws (confirmat screws) (source: Howard 2016), c a cabinet hinge showing side-toside adjustment screw (source: Dvortygirl 2007)
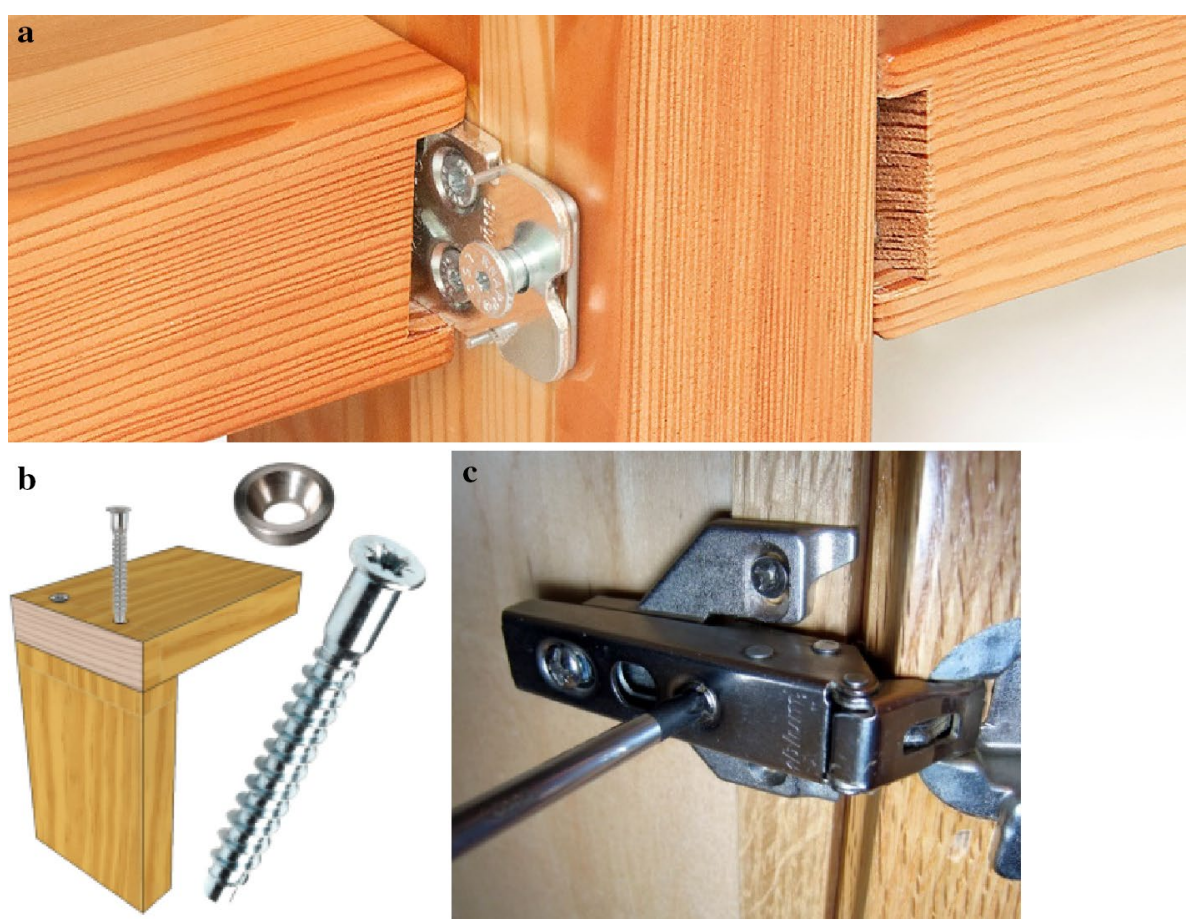


\section{Method for wood threaded fasteners patents search}

Patent documents were searched by means of several commonly available databases (Patent Lens, Google Patents, WIPO_-Patentscope). In some cases, the information was searched directly on the patent office's websites (EPOEsp@cenet, USPTO_Public PAIR, IPDL_Japanese Patent Office, SIPO_Chinese Patent Office, DPMA-German Patent and Trade Mark Office). For data analysis, a chosen "Software as a Service", which has a global patent coverage with full-text data, was used. In order to correctly identify patent documents relating to screws for wood materials a specific query was formulated. Patent documents containing the words "wood" and "screw" in "Title", "Abstract" or "Claim" ("TAC") fields and being classified at the same time in the International Patent Classification to the "F16B 25" classification group were searched. This group has the following structure (Section F. Mechanical Engineering; Lighting; Heating; Weapons; Blasting 2016):

- F16B 25/00 Screws that form threads in the body into which they are screwed, e.g. wood screws, self-tapping screws [2006.01]

- F16B 25/02 by a cutting and material removing action, e.g. fluted self-tapping screws [2006.01]

- F16B 25/04 by a slicing and material displacing action, e.g. wood screws with sharp thread crests [2006.01]

- F16B 25/06 by swaging, i.e. material deforming action [2006.01]

- F16B 25/08 by a combination of any two or all of the actions provided for in groups F16B 25/02-F16B 25/06 [2006.01]

- F16B 25/10 Screws performing an additional function to thread-forming, e.g. drill screws [2006.01]

All five above-mentioned subgroups of the "F16B 25" classification group were taken into account. All the screw inventions documented by patent applications since 1846 were taken into consideration; however, the inventions submitted to the national patent offices after 1902 have been analyzed more thoroughly. The inventions filed for patenting before 1902 were analyzed provided that modern patent documents refer to them.

\section{Results and discussion}

\subsection{Number and structure of patent documents relating to wood screws}

As a result of the query, 645 patent families containing 1157 patent documents from 1902 to 2016 have been initially identified. Subsequently, an overview and verification of the obtained pattern family list were carried out in order to remove from this list all patents that are not related to screws for wood based materials. Eventually, a collection was obtained consisting of 611 patent documents' families containing 1031 patent applications for the invention or decisions granting protection for the invention. The results of the described search are presented in Table 2.

As shown in Table 2, the classification group F16B 25 contains 5808 families of fastener inventions, among them threaded fasteners for wood-based materials constitute $9.5 \%$. The collection of IP (Intellectual property) documents consisting of 1031 patent documents related to screw inventions for wood-based materials contains $34 \%$ of utility models and $66 \%$ of industrial designs.

The term of a patent starts with the application at the patent office, then the application is published with the given priority date. After a few years, the applications with an appropriate level of inventiveness receive legal protection, and in the end (depending on the period that has been paid), this protection lapses. For each patented invention, five dates delimit this process: filed, priority, published, grant, expiry. The described sequence of dates in relation to the number of wood screw patents after 1902 is presented in Fig. 2.

As shown in Fig. 2, a significant increase in the number of patent applications took place at the beginning of the $1990 \mathrm{~s}$ and the maximum falls in the years 2000-2011 when the number of published patent applications increased from 16 up to 40 per year.

It is possible to point out several leading countries in the volume of submitted inventions. The greatest number of inventions comes from Japan, thereafter from China and Germany. In these three countries, about $60 \%$ of all

Table 2 Results of the search for threaded fasteners for wood materials patents

\begin{tabular}{lllll}
\hline Criteria & $\begin{array}{l}\text { Number of all patent } \\
\text { families in F16B 25 } \\
\text { group }\end{array}$ & $\begin{array}{l}\text { Number of all patent } \\
\text { documents in F16B 25 } \\
\text { group }\end{array}$ & $\begin{array}{l}\text { Number of wood screw } \\
\text { patent families in F16B 25 } \\
\text { group }\end{array}$ & $\begin{array}{l}\text { Number of wood screw patent } \\
\text { documents in F16B 25 group }\end{array}$ \\
\hline $\begin{array}{l}\text { Applications and granted } \\
\text { patents (1902-2017) }\end{array}$ & 5808 & 13545 & 611 & 1031 \\
$\begin{array}{l}\text { Granted patents (1902-2017) } \\
\text { 2916 }\end{array}$ & 6727 & 337 & 625 \\
\hline
\end{tabular}




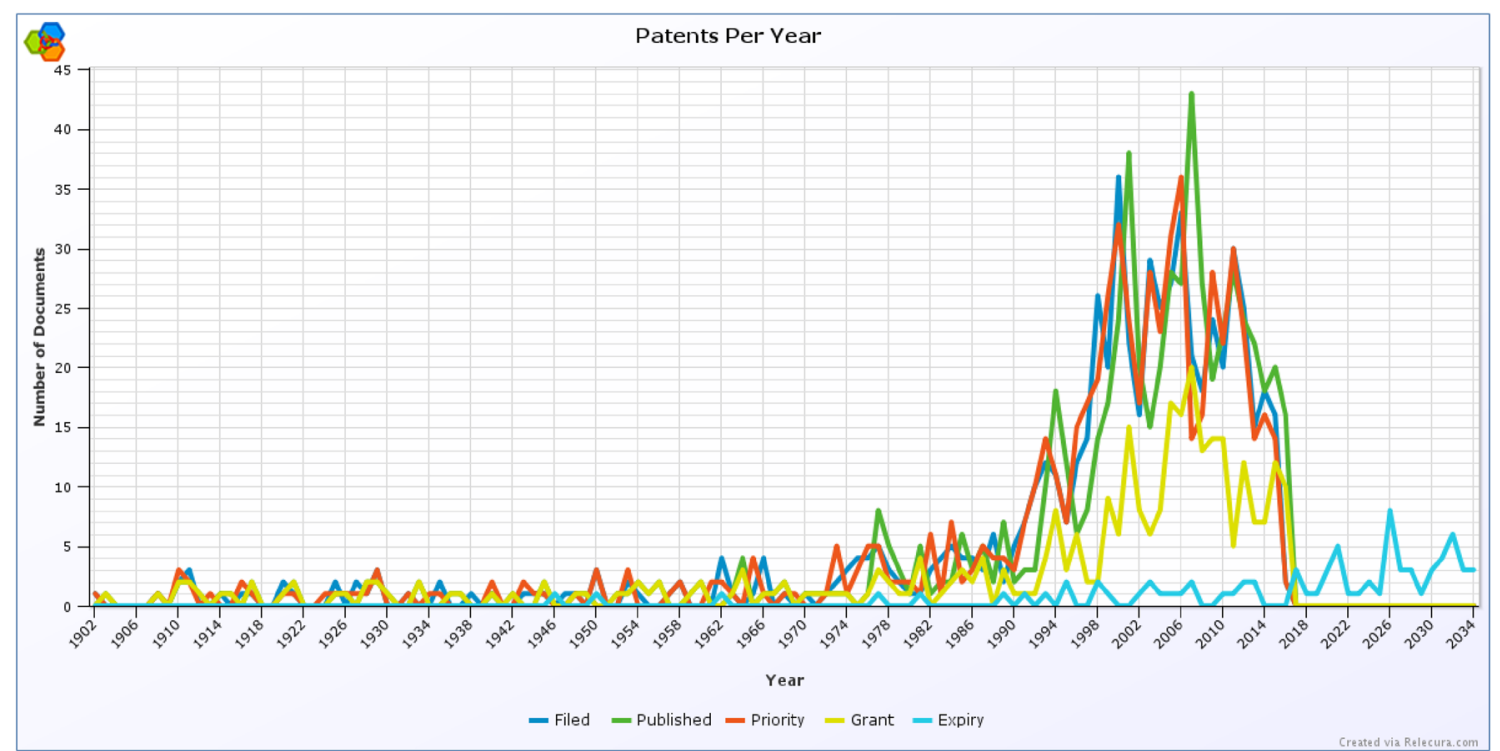

Fig. 2 Number of patents per year

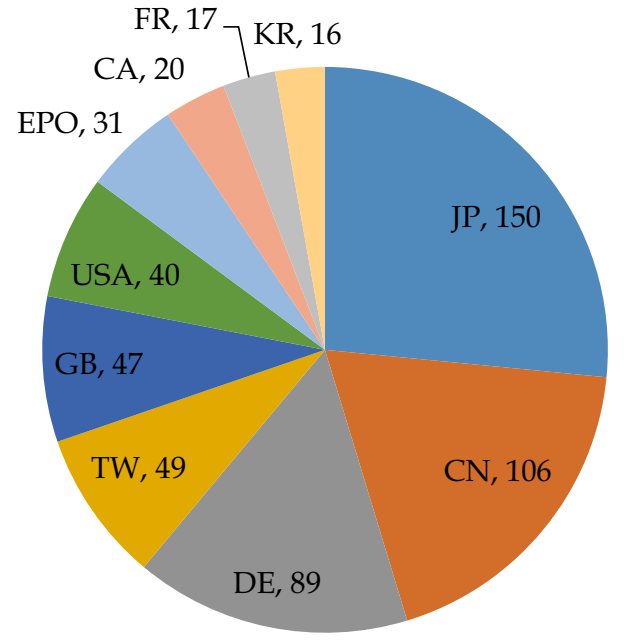

Fig. 3 Screw inventions per country (JP-Japan, CN-China, DEGermany, TW-Taiwan, GB-Great Britain, USA-USPTO, EPOEuropean Patent Office, CA-Canada, FR-France, KR-Republic of Korea)

screw inventions intended for wood-based materials were filed for patenting for the first time (Fig. 3).

Number of screw patents listed in Fig. 3, in particular countries with a breakdown by year, is presented in Fig. 4 .

Figure 5 reveals the share of the USA remains at a relatively stable level, decreasing share of Japan and Germany as well as increasing share of China in the number of inventions filed for patenting.

\subsection{Influence of patents on other patents and non-patent literature}

Pattern quality is usually determined by the following parameters: forward citations (citations received from subsequent patents), backward citations in the patent application, the number of claims and family size (Lanjouw and Schankerman 2004). The number of forward citations allows the measurement of: (1) the economic value of the invention, (2) the invention's impact on the development of other inventions (Gay and Le Bas 2005). An overview of the most-cited wood screw patents in other patent documents is presented in Fig. 5. It summarizes the 11 mostcited patent documents with several forward citations for each patent. The most-cited patent is mentioned in 87 other patent documents; at the same time, it is a patent with the highest annual number of citations.

The number of forward citations is correlated with the term of a patent; that is why, apart from the number of forward citations, Fig. 5 also contains the annual citation frequency of the most-cited patent documents. Two documents particularly stand out in this field: the US 5516248 A from 1996 cited 4.4 times per year and the US $6056491 \mathrm{~A}$ from 2000 cited 4.2 times per year.

Patents of economically beneficial inventions are extended for subsequent years despite the progressively increasing fee charged by the patent office each year. This correlation was confirmed by Harhoff and his team on the basis of the analyses carried out in the USA and Germany (Harhoff et al. 1999). They stated that the most-cited patents are covered at the same time by the maximal 20 -year 
Fig. 4 Top countries by published year

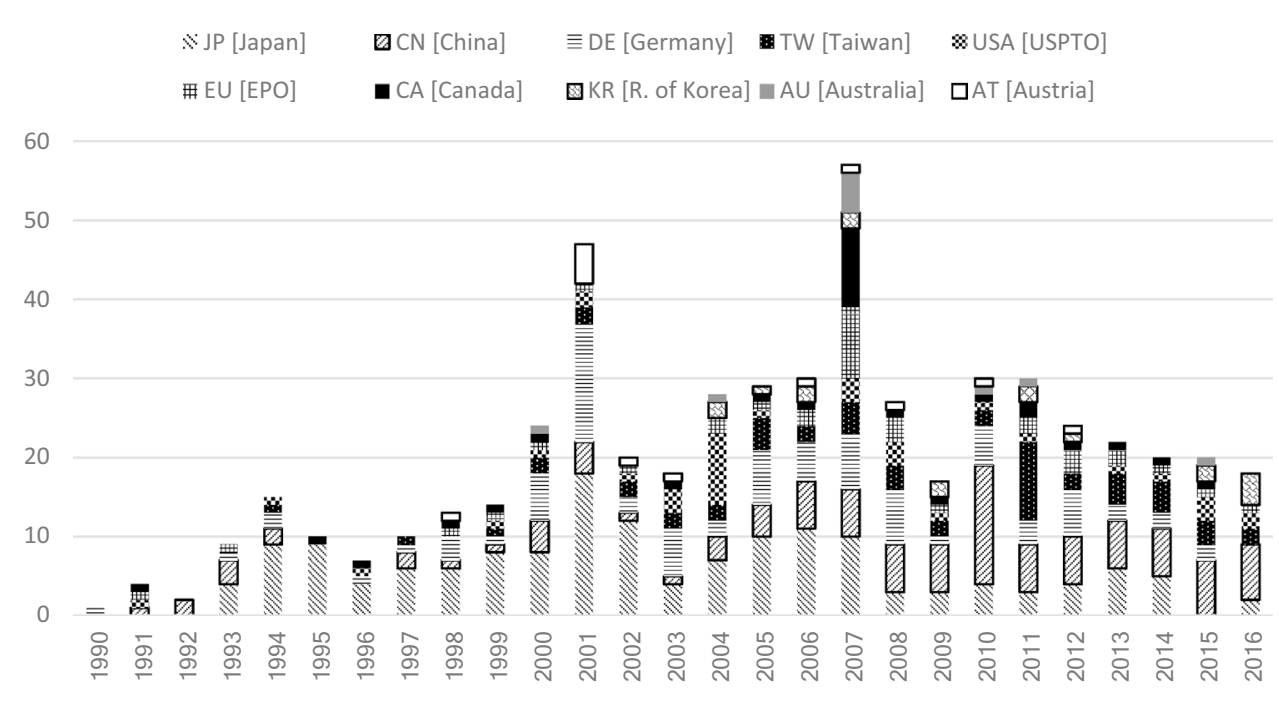

Only 32 patent documents cite non-patent literature (scholarly published work). Five patents with the biggest number of references are listed in Table 5.

No references in the scientific publications to the patents of screw for wood materials were found. One of the few exceptions is the scientific monography by Ulrich Hübner, which cites about 20 patent documents of wood screws (Hübner 2014) Potential reason for this may be the language of patent documents, which is different to the language of the scientific community and therefore, the relation of gaining the new knowledge to time consuming study is not satisfying.

\subsection{The most influential inventions relating to geometry of wood screws}

Fig. 5 An overview of the most-cited wood screws patents in other patent documents (the number of forward citations indicated for each patent) (DeHaitre 1996; Sparkes 1987; Hsu 2000; Burgard 1987; Kawashita 1989; McCauley et al. 1987; Dicke 2006b; Chen 2001; Hunt 1933; Bodin 2002; Simons 1989) (according to lens.org, 2017.07.10)

protection period. The oldest ten wood screw patents with still ongoing protection are presented in Table 3.

It is also possible to indicate the new patents for which the fee was paid many years in advance. They are also the solutions recognized as economically advantageous at the patent-pending stage. Table 4 contains such a summary.

Wood screws patents documents could also be analyzed in terms of number of citations that appear within them. The more citations there are, the wider is the description of the state of the art related to the invention filed for patenting. It has been stated that among the 611 identified patent documents, 582 patents quote other patents, while 43 patents quote from 11 to 20 other patents and only 26 patents quote over 20 other patents.
Some of the hundreds of identified patents are characterized by specific bibliometric features. They are presented in Table 6.

The most-cited modern patents are the descriptions of inventions tackling an important technical issue. The fact that patents cite some other patent document means that creators of more recent patent solutions declare in their patent applications that they found a better solution than the quoted patent. This implies that patents that are cited very often have very huge impact on the development of technology, but that the strength and statistical significance of this relationship varies across geographical regions and across channels of knowledge diffusion (Duguet and MacGarvie 2005). The biggest patent family contains a solution that is very interesting in terms of utility and merits being reserved over as large an area as possible (in many patent offices). The patent applications filed in subsequent patent offices entail the payment of the next fees; that is why only those patent solutions that were recognized as economically advantageous are filed in many patent offices (it is worth noting that limited patent DE 202004002877 U1 and 
Table 3 The oldest ten patents of wood screws with still ongoing protection

\begin{tabular}{|c|c|c|c|c|}
\hline Patent or patent application \# & $\begin{array}{l}\text { Number of } \\
\text { family mem- } \\
\text { bers }\end{array}$ & Title & Priority year & $\begin{array}{l}\text { Estimated } \\
\text { expiry year }\end{array}$ \\
\hline EP 0831239B1 (Schulte 1998) & 18 & Cutting screw & 1996 & 2017 \\
\hline NZ 328831 A [US 6109850 A (Commins 2000)] & 6 & $\begin{array}{l}\text { Screw fastener in metal connector to wood struc- } \\
\text { ture shear connection }\end{array}$ & 1996 & 2017 \\
\hline $\begin{array}{l}\text { DE } 29621923 \text { U1 (Wieland 1998) } \\
\text { [EP0849474A1 (Wieland and Litze 1998)] }\end{array}$ & 9 & Drill screw & 1996 & 2017 \\
\hline EP 0970312B1 (Petit 2000) & 8 & Novel wood screw with cut-out thread & 1997 & 2018 \\
\hline US 6152666A (Walther et al. 2000) & 14 & $\begin{array}{l}\text { Screw for use as a fastener in fibrous material } \\
\text { such as wood }\end{array}$ & 1998 & 2018 \\
\hline EP0984177B1 (Wieland 2000) & 5 & $\begin{array}{l}\text { Connecting screw for wood-concrete composite } \\
\text { structure }\end{array}$ & 1998 & 2019 \\
\hline $\begin{array}{l}\text { AU 2000/012778 A (Ulryck 2001) (FR } 2786229 \\
\text { B1) }\end{array}$ & 4 & Wood-screw or the like & 1998 & 2019 \\
\hline CA 2299129 C (Lindal 2008) & 4 & Waterproof joints between timbers & 1999 & 2020 \\
\hline US6056491A (Hsu 2000) & 1 & $\begin{array}{l}\text { Screw having cutting teeth formed on threads } \\
\text { thereof }\end{array}$ & 1999 & 2019 \\
\hline AU 760715 B2 (Saman and Gurong 2003) & 2 & Improvements relating to self-drilling screws & 1999 & 2020 \\
\hline
\end{tabular}

Table 4 The longest protected patents of wood screws

\begin{tabular}{|c|c|c|c|}
\hline Publication \# & Title & Priority year & Expiry year \\
\hline US 20160146241 A1 (Eckert and Wunderlich 2016) & $\begin{array}{l}\text { Wood screw with intermediate thread sections tapering } \\
\text { to the front }\end{array}$ & 2013 & 2034 \\
\hline EP 2811182 A1 (Humm et al. 2014) & $\begin{array}{l}\text { Screw for drilling and tapping in a first supporting } \\
\text { surface section and a harder second supporting surface } \\
\text { section }\end{array}$ & 2013 & 2034 \\
\hline $\begin{array}{l}\text { US } 20160115989 \text { A1 (Hubmann 2014, Patent applica- } \\
\text { tion) }\end{array}$ & Screw & 2013 & 2034 \\
\hline US 20150308481 A1 (Dissing 2015) & Method and screw for mounting fiber cement planks & 2012 & 2033 \\
\hline US 9145911 B2 (Shih 2015) & Anti-split wood screw & 2013 & 2033 \\
\hline US 8998550 B2 (Platt 2015) & Hardware attachment system & 2013 & 2033 \\
\hline EP 2669879 A2 (Rössner 2013) & $\begin{array}{l}\text { Safety system for construction of a structure with a } \\
\text { wooden component and structure produced using such } \\
\text { a safety system }\end{array}$ & 2012 & 2033 \\
\hline US 8905696 B2 (Lapointe 2014) & Extension fastener for portable tool & 2012 & 2033 \\
\hline EP 2633959 B1 (Simon and Simon 2013) & $\begin{array}{l}\text { Device for securing the wooden handle in the eye of a } \\
\text { hammer head and screw for attaching a wooden handle } \\
\text { in the eye of a hammer head }\end{array}$ & 2012 & 2033 \\
\hline US 9377045 B2 (Su and $\mathrm{Su} 2016)$ & Wood screw & 2012 & 2032 \\
\hline
\end{tabular}

limited patent DE 29906200 U1 were proposed by the same inventor and are representatives of two large patent families). Patents that cite many other patents are patents that describe the state of the art very widely. It may be expected that a design problem has been identified within them, an entire sequence of proposed solutions from the older patent documents has been quoted and in the end, one's own solution to respond to this problem has been presented. The oldest presently cited screw patents contain solutions for fundamental issues. These issues are still relevant today, which was reflected by the fact that, despite the passage of time, they are still quoted in the new patents. The most cited patent in modern patent applications is the US 126366 A from 1872 that was quoted in 165 patent documents. This patent describes a solution that significantly decreases resistance encountered while driving a screw.

\section{Conclusion}

In global patent literature, it is possible to identify over 600 patent documents related to screws for wood-based materials. After analysing these patents, it can be stated that: 
Table 5 Number of non-patent literature cited in patents

\begin{tabular}{ll}
\hline Patent no., filed, reference & $\begin{array}{l}\text { No. of cited non- } \\
\text { patent literature }\end{array}$ \\
\hline US 7832173 B2 (2000) (Crawford et al. 2010) & 18 \\
US 9482258 B2 (2012) (Park 2016) & 16 \\
US 7189045 B2 (2004) (Mcgovern and Druschel & 10 \\
2008) & \\
US 7367768 B2 (2007) (Mcgovern and Druschel & 10 \\
2007) & \\
US 9051726 B2 (2013) (Vandenberg 2014) & 6 \\
\hline
\end{tabular}

Patents US 7189045 B2 and US 7367768 B2 are in the same patents family

1. In the recent hundred years a significant increase in the number of patent applications took place at the beginning of the 1990s and the maximum falls in the years 2000-2011. There are several leading countries in the number of submitted inventions of screws for wood materials. The greatest number of inventions comes from Japan, thereafter from China and Germany. Over recent years, the share of Japan and Germany decreases; the share of China increases in the number of inventions filed for patenting for the first time.

2. By filtering patents by two very important indicators, the number of forward citations and the size of patent families, it can be observed that there are only a few significant patent documents for other patent applications, 13 of them are listed in Table 5.

3. Patents have very poor interactions with non-patent literature. Patents are very little cited in non-patent literature, especially not cited in scientific literature. Only 32 patent documents cite non-patent literature.

The most important patents tackle the following issues: reduction of the friction encountered while driving a screw
(DeHaitre 1996; Hughes 2017), reduction of the risk of wood cracking while driving a screw (Shih 2015), improvement of the self-drilling of the pilot hole (Sparkes 1987; Humm et al. 2014), improvement of the thread forming in a workpiece, protection against unscrewing (Taneichi 2013) and improvement of the installation of the screws. These issues may be considered the most important technical challenges in construction of the screws for wood-based materials. Patents of screws recognized as the most influential are presented in Table 7. This table shows the most crucial screw patents and contains information concerning a type of issue that was solved by each of these patents, therefore it constitutes a synthetic summary of the patent document analysis results described in this article.

The problems of the crucial patents shown in Table 6 do not quite correspond with the topics of published research papers concerning screws for wood-based materials. A major concern for the scientists is the screws' pull-out resistance (Eckelman 1988; Rajak and Eckelman 1993; Erdil et al. 2002; Özçifçi 2009; Hübner et al. 2010; Kariz et al. 2013; Sydor et al. 2015; Sydor and Wołpiuk 2016a, b; Gaunt 1997; Ayyildiz and Malkocoglu 2001; Aytekin 2008; Gates 2009; Wołpiuk and Pohl 2009; Pohl and Wołpiuk 2011; Tankut 2011; Hübner 2014; Kasal et al. 2014; Semple et al. 2014; Taşçioğlu et al. 2014; Gašparík et al. 2015; Wołpiuk and Sydor 2016; Ringhofer 2017). This property is usually analyzed from the point of view of changing constructive properties of wooden workpieces, (Eckelman 1988; Rajak and Eckelman 1993; Erdil et al. 2002; Hübner et al. 2010; Kariz et al. 2013; Sydor and Wołpiuk 2016a; Ayyildiz and Malkocoglu 2001; Aytekin 2008; Gates 2009; Wołpiuk and Pohl 2009; Pohl and Wołpiuk 2011; Tankut 2011; Kasal et al. 2014; Semple et al. 2014; Taşçioğlu et al. 2014; Gašparík et al. 2015; Wołpiuk and Sydor 2016), less often from the point of view of the screws' shapes (e.g. influence of the tip on the screw features: Gahagan and Newlin 1938;

Table 6 Summary of the wood screw patents analysis results

\begin{tabular}{|c|c|c|}
\hline Feature & $\begin{array}{l}\text { Patent and application numbers, dates and bibliographic } \\
\text { references }\end{array}$ & Substantiation \\
\hline No. of forward citations & $\begin{array}{l}\text { US 5516248A (1996) (DeHaitre 1996) } \\
\text { US 4697969A (1987) (Sparkes 1987) } \\
\text { US 6056491A (2000) (Hsu 2000) }\end{array}$ & $\begin{array}{l}\text { Cited } 87 \text { times (by other patents) } \\
\text { Cited } 84 \text { times (by other patents) } \\
\text { Cited } 67 \text { times (by other patents) }\end{array}$ \\
\hline $\begin{array}{l}\text { The largest families of patents and patent } \\
\text { applications }\end{array}$ & $\begin{array}{l}\text { IL 46025 D0 (Rosan and Reece 2018) } \\
\text { CA 2827504A1 (Vandenberg 2014) } \\
\text { DE 29906200 U1 (Dicke 1999) } \\
\text { DE 202004002877 U1 (Dicke 2006a) }\end{array}$ & $\begin{array}{l}29 \text { members (1975-1981) } \\
24 \text { members (2011-2015) } \\
22 \text { members (1999-2009) } \\
21 \text { members (2005-2011) }\end{array}$ \\
\hline No. of backwards citations & $\begin{array}{l}\text { US } 9482258 \text { B2 (2016) (Park 2016) } \\
\text { US } 9051726 \text { B2 (2005) (Vandenberg 2014) } \\
\text { US 8480343B2 (1013) (Vandenberg 2014) }\end{array}$ & $\begin{array}{l}\text { Cites } 176 \text { patents } \\
\text { Cites } 155 \text { patents } \\
\text { Cites } 148 \text { patents }\end{array}$ \\
\hline $\begin{array}{l}\text { The oldest patents cited by contemporary } \\
\text { patents }\end{array}$ & $\begin{array}{l}\text { US } 4704 \text { A (1846) } \\
\text { US } 24393 \text { A (1859) } \\
\text { US } 126366 \text { A (1872) (Wills 1872) }\end{array}$ & $\begin{array}{l}\text { Cited by } 4 \text { patents }(1952-2008) \\
\text { Cited by } 5 \text { patents }(1972-2009) \\
\text { Cited by } 165 \text { patents }(1952-2014)\end{array}$ \\
\hline
\end{tabular}


Table 7 The most influential inventions relating to geometry of wood screws

\begin{tabular}{|c|c|c|}
\hline Bibliographic data & Substantiation & Essence of the invention \\
\hline US 5516248 (1996) (DeHaitre 1996) & Cited 87 times ( 4.4 times per year) & $\begin{array}{l}\text { Reducing the friction between the } \\
\text { screw shank and the workpiece }\end{array}$ \\
\hline US 4697969 (1987) (Sparkes 1987) & Cited 84 times (2.9 times per year) & Improved self-drilling \\
\hline US 6056491 (2000) (Hsu 2000) & Cited 67 times ( 4.2 times per year) & Prevent the wood from being cracked \\
\hline US 126366 (1872) (Wills 1872) & Cited 165 times (1.1 times per year) & $\begin{array}{l}\text { Boring a pilot hole } \\
\text { Reducing the friction } \\
\text { Prevent the wood from being cracked }\end{array}$ \\
\hline IL 46025 D0 (1975) (Rosan and Reece 2018) & Patent family with 29 members & Improved self-drilling \\
\hline CA 2725335 A1 (2010) (Vandenberg 2014) & Patent family with 24 members & $\begin{array}{l}\text { Improved wood screw and improved } \\
\text { its installation method }\end{array}$ \\
\hline DE 29906200 U1 (1999) (Dicke 1999) & Patent family with 22 members & Protection against unscrewing \\
\hline DE 202004002877 U1 (2004) (Dicke 2006a) & Patent family with 21 members & Improved thread forming in workpiece \\
\hline
\end{tabular}

Pirnbacher et al. 2009)). This points to the very small correlation between the two important areas of human activity in threaded fasteners for wood materials: science pole and technological pole described by patent documents (in the sense of techno-economic networks described by Bell and Callon 1994).

Acknowledgements The author would like to thank Jacek Sydor who helped improve this manuscript.

Open Access This article is distributed under the terms of the Creative Commons Attribution 4.0 International License (http://creativeco mmons.org/licenses/by/4.0/), which permits unrestricted use, distribution, and reproduction in any medium, provided you give appropriate credit to the original author(s) and the source, provide a link to the Creative Commons license, and indicate if changes were made.

\section{References}

Abbas A, Zhang L, Khan SU (2014) A literature review on the stateof-the-art in patent analysis. World Patent Inf 37:3-13. https://doi. org/10.1016/j.wpi.2013.12.006

Agricola G (1950) De Re Metallica: translated from the first Latin edition of 1556 with biographical introduction annotations and appendices upon the development of mining methods, metallurgical processes, geology, mineralogy \& mining law from the earliest times to the 16 th century by H.C. Hoover and L.H. Hoover. Translated by Herbert Clark Hoover and Lou Henry Hoover. Dover Publications, Inc., New York

Altshuller GS, Shapiro RB (1956) О психологии изобретательского творчества. (On the psychology of inventive creation). Вопросы Психологии. (The Psychological Issues) 6:37-39

Aytekin A (2008) Determination of screw and nail withdrawal resistance of some important wood species. Int J Mol Sci 9(4):626-637

Ayyildiz H, Malkocoglu A (2001) Wood screw withdrawal resistance of some important tree species growing in Eastern Blacksea Region. J Artvin Kafkas For Fac 2(1):1

Bell G, Callon M (1994) Techno-economic networks and science and technology policy. STI Rev 14:67-126

Blaß HJ, Siebert W (1999) Ermittlung Der Einschraub- Und Bruchdrehmomente von Schrauben. (Determination of the screwing and breaking torques of screws) Karlsruhe: Versuchsanstalt für Stahl Holz und Steine, Abteilung Ingenieurholzbau, Universität Fridericiana. http://holz.vaka.kit.edu/public/101.pdf. Accessed 17 Mar 2018

Bodin RG (2002) Mounting apparatus having a swivel head. USPTO US 6443680 B1, filed May 4, 2001. http://patft.uspto.gov/netac gi $/$ nph-Parser?Sect $1=$ PTO $2 \&$ Sect $2=$ HITOFF $\& p=1 \& \mathrm{u}=\% 2$ Fnet ahtml \% 2FPTO $\% 2$ Fsearch-bool.html\&r $=1 \& \mathrm{f}=\mathrm{G} \& \mathrm{l}=50 \&$ $\operatorname{co} 1=$ AND $\& d=$ PTXT \& $s 1=6443680 . P N . \& O S=P N / 64436$ 80\&RS=PN/6443680. Accessed 7 Jul 2017

Branowski B, Zabłocki M, Sydor M (2018) Experimental analysis of new furniture joints. BioResources 13(1):370-382. https://doi. org/10.15376/biores.13.1

Burgard FA (1987) Mounting device and method of use. USPTO US 4636125, filed November 29, 1984. http://patft.uspto.gov/netac gi/nph-Parser?Sect $1=$ PTO2 $\&$ Sect $2=$ HITOFF $\& p=1 \& u=\% 2 F$ et ahtml $\%$ 2FPTO $\% 2$ Fsearch-bool.html\&r=1\&f=G\&l=50\& $\operatorname{co} 1=\mathrm{AND} \& \mathrm{~d}=\mathrm{PTXT} \& \mathrm{~s} 1=4636125 . \mathrm{PN} . \& \mathrm{OS}=\mathrm{PN} / 46361$ $25 \& \mathrm{RS}=\mathrm{PN} / 4636125$. Accessed 7 Jul 2017

Chen C-C (2001) Screw with spiral triangular threads. UP TO US 6254327 B1, filed December 1, 1999. http://patft.uspto .gov/netacgi/nph-Parser?Sect $1=$ PTO $2 \&$ Sect $2=$ HITOF $\mathrm{F} \& \mathrm{p}=1 \& \mathrm{u}=\% 2 \mathrm{Fnet}$ ahtm $1 \% 2 \mathrm{FPTO} \% 2 \mathrm{Fsearch}-\mathrm{bool} . \mathrm{htm}$ $1 \& \mathrm{r}=1 \& \mathrm{f}=\mathrm{G} \& \mathrm{l}=50 \& \mathrm{co} 1=\mathrm{AND} \& \mathrm{~d}=\mathrm{PTXT} \& \mathrm{~s} 1=62543$ 27.PN.\&OS=PN/6254327\&RS=PN/6254327. Accessed $7 \mathrm{Jul}$ 2017

Commins AD (2000) Screw fastener in metal connector to wood structure shear connection. USPTO US 6109850 A, filed August 29, 1997. http://patft.uspto.gov/netacgi/nph-Parser?Sect1 $=$ PTO $2 \&$ Sect $2=$ HITOFF $\& p=1 \& u=\% 2$ Fnetahtm $1 \% 2$ FPTO $\% 2$ Fsearch-bool.html\& $\mathrm{r}=1 \& \mathrm{f}=\mathrm{G} \& \mathrm{l}=50 \& \mathrm{co} 1=\mathrm{AND} \& \mathrm{~d}=\mathrm{PT}$ $\mathrm{XT} \& \mathrm{~s} 1=6109850 . \mathrm{PN} . \& \mathrm{OS}=\mathrm{PN} / 6109850 \& \mathrm{RS}=\mathrm{PN} / 6109850$. Accessed 9 Jul 2017

Crawford MG, Pryor SE, Commins AD (2010) Screw fastener in multiple floor truss and wood-to-wood shear connection. USPTO US 7832173 B2, filed December 1, 2000. https://www.lens.org/lens/ patent/US_7832173_B2. Accessed 26 Aug 2017

DeHaitre L (1996) Low torque wood screw. USPTO US 5516248A, filed September 7, 1994. http://patft.uspto.gov/netacgi/nph-Parse $\mathrm{r}$ ?Sect $2=\mathrm{PTO} 1 \&$ Sect $2=$ HITOFF $\& \mathrm{p}=1 \& \mathrm{u}=/$ netahtml $/ \mathrm{PTO} / \mathrm{searc}$ h-bool.html\&r=1\&f=G\&l=50\&d=PALL\&RefSrch=yes\&Query $=\mathrm{PN} / 5516248$. Accessed $7 \mathrm{Jul} 2017$

Dicke R (1999) Senkkopfschraube. (Countersunc screw) DPMA DE 29906200 U1, filed April 7, 1999. https://worldwide. espacenet.com/publicationDetails/biblio? $\mathrm{II}=0 \& \mathrm{ND}=3 \&$ adjac 
en $\mathrm{t}=\mathrm{true} \& 1$ oc al e $=$ en_EP \& FT $=\mathrm{D} \& \mathrm{~d}$ a te $=20000$ $907 \& C C=D E \& N R=29906200 \mathrm{U} 1 \& \mathrm{KC}=\mathrm{U} 1$. Accessed $9 \mathrm{Jul} 2017$

Dicke R (2006a) Gewindeformende Schraube. (Self-tapping Screw) DPMA DE 202004002877 U1, filed February 25, 2004. https://worldwide.espacenet.com/publicationDetails/bibli o? $\mathrm{CC}=\mathrm{DE} \& \mathrm{NR}=202004002877 \mathrm{U} 1 \& \mathrm{KC}=\mathrm{U} 1 \& \mathrm{FT}=\mathrm{D}$. Accessed 9 Jul 2017

Dicke R (2006b) Self-tapping screw for composite materials. USPTO US 7037059 B2, filed January 6, 2004. http://patft.uspto.gov/netac gi/nph-Parser?Sect $1=$ PTO2 \&Sect $2=$ HITOFF $\& p=1 \& u=\% 2$ Fnet ahtml $\% 2$ FPTO $\% 2$ Fsearch-bool.html\&r=1\&f=G\&l=50\&co $1=$ AND\&d=PTXT \&s $1=\% 22 \mathrm{US}+20040141827+\mathrm{A} 1 \% 22 \& \mathrm{OS}=$. Accessed 7 Jul 2017

Dissing CH (2015) Method and screw for mounting fiber cement planks. USPTO AU 2013/350147 B2 (granted patent since 2017.04.20), filed October 29, 2015. http://patft.uspto.gov/netac gi/nph-Parser?Sect $2=$ PTO $1 \&$ Sect $2=$ HITOFF $\& p=1 \& u=/$ netah $\mathrm{tml} / \mathrm{PTO} /$ search-bool.html\&r=1\&f=G\&l=50\&d=PALL\&RefSr $\mathrm{ch}=\mathrm{yes} \&$ Query $=\mathrm{PN} / 9845819$. Accessed 19 Sep 2017

Duguet E, MacGarvie M (2005) How well do patent citations measure flows of technology? Evidence from French innovation surveys. Econ Innov New Technol 14(5):375-393. https://doi. org/10.1080/1043859042000307347

Dvortygirl (2007) A Euro style cabinet hinge showing side-to-side adjustment screw [Photography, Uploader License: Creative Commons]. https://www.wikihow.com/images/thumb/1/16/ Euro_hinge_3.jpg/900px-Euro_hinge_3.jpg. Accessed 29 Oct 2017

Eckelman C (1988) The withdrawal strength of screws from commercially available medium density fiberboard. For Prod J 38(5):21-24

Eckert R, Wunderlich A (2016) Wood screw with intermediate thread sections tapering to the front. US 20160146241 A1, filed June 25, 2014. https://www.google.pl/patents/US20160146241. Accessed 26 May 2016

Erdil YZ, Zhang J, Eckelman CA (2002) Holding strength of screws in plywood and oriented strandboard. For Prod J 52(6):55

Eurocode 5: Design of Timber Structures: Part 1-1: GeneralCommon Rules and Rules for Buildings (2004) EN 19951-1:2004 + A 1. European Committee for Standardization CEN

Gahagan JM, Newlin JA (1938) Lag-screw joints: their behavior and design. U.S. Dept. of Agriculture, Washington. https://ir.libra ry.oregonstate.edu/concern/defaults/cn69m888f. Accessed 21 Mar 2018

Gašparík M, Barcík S, Borůvka V, Holeček T (2015) Impact of thermal modification of spruce wood on screw direct withdrawal load resistance. Bioresources 10(1):1790-1802

Gates JC (2009) Screw withdrawal strength in 9Wood's Assemblies. Oregon Wood Innovation Center, Test Evaluation Report. http://www.9wood.com/files/rd_reports/screw_withdrawl.pdf. Accessed 21 Mar 2018

Gaunt D (1997) The effect of thread geometry on screw withdrawal strength. N Z Timber Des J 6(3):12-20

Gay C, Le Bas C (2005) Uses without too many abuses of patent citations or the simple economics of patent citations as a measure of value and flows of knowledge. Econ Innov New Technol 14(5):333-338

Harhoff D, Narin F, Scherer FM, Vopel K (1999) Citation frequency and the value of patented inventions. Rev Econ Stat 81(3):511515. https://doi.org/10.1162/003465399558265

Howard G (2016) Knock down fittings, brackets and plates. DT Online (blog). http://wiki.dtonline.org/index.php/Knock _Down_Fittings,_Brackets_and_Plates. Accessed 24 Jun 2016

Hsu K-T (2000) Screw having cutting teeth formed on threads thereof. USPTO US 6056491, filed April 23, 1999. lens. org/084-263-267-617-985. Accessed 2 May 2000
Hubmann G (2018) Screw. US10054147B2, filed May 23, 2014. http://appft1.uspto.gov/netacgi/nph-Parser?Sect1 $=\mathrm{PTO} 1 \&$ Sect $2=$ HITOFF $\& \mathrm{~d}=\mathrm{PG} 01 \& \mathrm{p}=1 \& \mathrm{u}=/$ netahtml$/ \mathrm{PTO} /$ srchnum.html\&r=1\&f=G\&l=50\&s 1=20160115989.PGNR. Accessed 29 Oct 2018

Hübner U (2014) Mechanische Kenngrößen von Buchen-, EschenUnd Robinienholz Für Lastabtragende Bauteile. (Mechanical Characteristics of Beech, Ash and Robinia Wood for Loaded Structural Elements) vol 3. Monographic Series TU Graz. Timber Engineering \& Technology. Verlag der Technischen Universität Graz, Graz. http://lamp.tugraz.at/ karl/verlagspdf/huebn er.pdf. Accessed 20 Mar 2018

Hübner U, Rasser M, Schickhofer G (2010) Withdrawal capacity of screws in European ash (Fraxinus excelsior L.). W 11th World Conference on Timber Engineering 2010 (WCTE 2010) (T. 1, s. 241-250). Trentino, Italy: Trees and Timber Institute, National Research Council. http://support.sbcindustry.com/ Archive/2010/june/Paper_031.pdf. Accessed 18 Jun 2017

Hughes BJ (2017) Low energy screws for wood and similar materials. USPTO US 9297402 B2, filed March 16, 2010. http://www. freepatentsonline.com/9297402.html. Accessed 29 Mar 2017

Humm S, Eckert R, Wunderlich A (2014) Screw for drilling and tapping in a first supporting surface section and a harder second supporting surface section. EP2811182(A1). https://worldwide. espacenet.com/publicationDetails/biblio $? \mathrm{FT}=\mathrm{D} \&$ date $=20141$ $210 \& D B=\& 1$ oc al e $=$ en_EP \& CC $=E P \& N R=28111$ $82 \mathrm{~A} 1 \& \mathrm{KC}=\mathrm{A} 1 \& \mathrm{ND}=4$. Accessed $7 \mathrm{Jul} 2017$

Hunt EF (1933) Combination machine and wood screw. US 1897196 A, filed August 21, 1929. http://www.google.pl/patents/US189 7196. Accessed 7 Jul 2017

Kariz M, Kitek Kuzman M, Sernek M (2013) The effect of heat treatment on the withdrawal capacity of screws in spruce wood. Bioresources 8(3):4340-4348

Kasal ANY, Zhang J, Erdil YZ, Demirci S (2014) Effect of material properties and anchorage location on load-bearing capacity of screw-connected and hung cabinets. Wood Fiber Sci 46(1):1-10

Kawashita F (1989) Wood screw with chip removing portion. UPTO US 4874278, filed August 31, 1987. http://patft.uspto.gov/netac gi/nph-Parser?Sect $1=$ PTO2 $\&$ Sect $2=$ HITOFF $\& p=1 \& u=\% 2$ Fnet ahtml \%2FPTO $\% 2$ Fsearch-bool.html \& $\mathrm{r}=1 \& \mathrm{f}=\mathrm{G} \& \mathrm{l}=50 \&$ $\mathrm{co} 1=\mathrm{AND} \& \mathrm{~d}=\mathrm{PTXT} \& \mathrm{~s} 1=4874278 . \mathrm{PN} . \& \mathrm{OS}=\mathrm{PN} / 48742$ $78 \& \mathrm{RS}=\mathrm{PN} / 4874278$. Accessed $7 \mathrm{Jul} 2017$

Lanjouw JO, Schankerman M (2004) Patent quality and research productivity: measuring innovation with multiple indicators. Econ J 114(495):441-465. https://doi.org/10.111 1/j.1468-0297.2004.00216.x

Lapointe D (2014) Extension fastener for portable tool. US 8905696 B2, filed November 26, 2012. http://patft.uspto.gov/netacgi/nphParser?Sect $1=$ PTO $2 \&$ Sect $2=$ HITOFF $\& p=1 \& u=\% 2$ Fnetahtml \%2FPTO $\% 2$ Fsearch-bool.html\&r=1\&f=G\&l=50\&co1=AND\& $\mathrm{d}=\mathrm{PTXT} \& \mathrm{~s} 1=8905696 . \mathrm{PN} . \& \mathrm{OS}=\mathrm{PN} / 8905696 \& \mathrm{RS}=\mathrm{PN} / 89056$ 96. Accessed 7 Jul 2017

Lindal W (2008) Waterproof joints between timbers. Canadian Patent Office CA 2299129 C, filed February 26, 1999. https://worldwide. espacenet.com/publicationDetails/biblio?CC $=$ CA\&NR $=22991$ $29 \mathrm{C} \& \mathrm{KC}=\mathrm{C} \& \mathrm{FT}=\mathrm{D}$. Accessed $9 \mathrm{Jul} 2017$

Mann D (2001) An introduction to TRIZ: the theory of inventive problem solving. Creativity Innov Manag 10(2):123-125

McCauley JR, Smallwood TL, Welliver P (1987) Wood-metal drill screw. USPTO US 4645396, filed December 19, 1984. http:// patft.uspto.gov/netacgi/nph-Parser?Sect $1=$ PTO2\&Sect2 $=$ HITOFF $\& p=1 \& u=\% 2$ Fnetahtml $\% 2$ FPTO $\% 2$ Fsearch-bool. $\mathrm{htm} 1 \& \mathrm{r}=1 \& \mathrm{f}=\mathrm{G} \& 1=50 \& \mathrm{co} 1=$ AND $\& \mathrm{~d}=$ PTXT $\& \mathrm{~s} 1=46453$ 96.PN.\&OS=PN/4645396\&RS=PN/4645396. Accessed 7 Jul 2017 
Mcgovern HT, Druschel T (2007) Deck screws suitable for use with composite lumber. USPTO US 7189045 B2, filed April 21, 2004. https://www.lens.org/lens/patent/US_7189045_B2. Accessed 26 Aug 2017

Mcgovern HT, Druschel T (2008) Deck screw and installation method for composite lumber. USPTO US 7367768 B2, filed February 7, 2007. https://www.lens.org/lens/patent/US_7367768_B2. Accessed 26 Aug 2017

Section F. Mechanical Engineering; Lighting; Heating; Weapons; Blasting (2016) The International Patent Classification (IPC). Geneva, Switzerland: The World Intellectual Property Organization (WIPO). http://www.wipo.int/classifications/ipc/en/ITsup port/. Accesed 28 Oct 2016

Özçifçi A (2009) The effects of pilot hole, screw types and layer thickness on the withdrawal strength of screws in laminated veneer lumber. Mater Des 30(7):2355-2358. https://doi.org/10.1016/j. matdes.2008.11.001

Park JS (2016) Fastener with multiple threaded regions. USPTO US 9482258, filed May 10, 2012. http://patft.uspto.gov/netacgi/nphParser?Sect $1=$ PTO $2 \&$ Sect $2=$ HITOFF $\& p=1 \& u=\% 2$ Fnetahtml \%2FPTO $\% 2$ Fsearch-bool.html\&r=1\&f=G\&l=50\&co1=AND\& $\mathrm{d}=\mathrm{PTXT} \& \mathrm{~s} 1=9482258 . \mathrm{PN} . \& \mathrm{OS}=\mathrm{PN} / 9482258 \& \mathrm{RS}=\mathrm{PN} / 94822$ 58. Accessed 7 Jul 2017

Petit P-Y (2000) Novel wood screw with cut-out thread. EP0970312 (A1) Abstract of corresponding document: FR2761424 (A1). https://worldwide.espac enet.com/publicationDeta ils $/$ bibli o $? F T=D \&$ date $=20000112 \& D B=\&$ local e $=$ en $\mathrm{EP} \& \mathrm{CC}=\mathrm{EP} \& \mathrm{NR}=0970312 \mathrm{~A} 1 \& \mathrm{KC}=\mathrm{A} 1 \& \mathrm{ND}=4$. Accessed 7 Jul 2017

Pirnbacher G, Schickhofer G (2007) Schrauben Im Vergleich-Eine Empirische Betrachtung. (Screw comparison-an empirical consideration). In: 6. GraHFT'07, F1-22. Verlag der Technischen Universität Graz, Graz. www.tib.eu/en/search/download/?tx_tibse arch_search\%5Bdocid\%5D=TIBKAT\%3A597858705\&tx_tibse arch_search $\% 5$ Bsearchspace $\% 5 \mathrm{D}=$ tibub\&cHash $=9608400 \mathrm{f} 99$ 9f2f38e016d5d433021dee. Accessed 20 Mar 2018

Pirnbacher G, Brandner R, Schickhofer G (2009) Base parameters of self-tapping screws. In: Proceedings of CIBW18, 42:42-47. Dübendorf, Schweiz: International Council for Research and Innovation in Building and Construction. Working Commission W18-Timber Structures. http://cib-w18.com/proceedings. Accessed 20 Mar 2018

Platt JM (2015) Hardware attachment system. USPTO US 8998550 B2, filed February 11, 2013. http://patft.uspto.gov/netacgi/nphParser?Sect $1=$ PTO $2 \&$ Sect $2=$ HITOFF $\& \mathrm{p}=1 \& \mathrm{u}=\% 2$ Fnetahtml \%2FPTO \%2Fsearch-bool.html\&r=1\&f=G\&l=50\&co1=AND\& $\mathrm{d}=$ PTXT\& $\mathrm{s} 1=8998550 . \mathrm{PN} . \& O S=\mathrm{PN} / 8998550 \& \mathrm{RS}=\mathrm{PN} / 89985$ 50. Accessed 7 Jul 2017

Pohl P, Wołpiuk M (2011) Local modification of screw connections in wood-based composites. Комп'ютерні Системи Проектування Теорія і Практика. (Computer Systems of Designing. Theory and Practice), (711), 124-131. http://vlp.com.ua/taxonomy/ term/3211. Accessed 26 Mar 2018

Rajak ZIBHA, Eckelman CA (1993) Edge and face withdrawal strength of large screws in particleboard and medium density fiberboard. For Prod J 43(4):25-30

RICON (2017) Connecting systems for modern post-beam woodglass-facades. KNAPP (blog). http://www.knapp-verbinder.com/ en/products/post-beam-wood-glass-facade. Accessed 8 Jul 2017

Ringhofer A (2017) Axially loaded self-tapping screws in solid timber and laminated timber products. Doctoral Thesis, Graz: Graz University of Technology, Institute of Timber Engineering and Wood Technology

Rosan J, Reece MP (1977) Self-boring fastener and methods of use thereof. US 4015504, filed November 15, 1973. http:// patft.uspto.gov/netacgi/nph-Parser?Sect $2=$ PTO $1 \&$ Sect 2
$=$ HITOF F \& p $=1 \& \mathrm{u}=/$ netah tml/PTO/searc h-bool. $\mathrm{htm} 1 \& \mathrm{r}=1 \& \mathrm{f}=\mathrm{G} \& \mathrm{l}=50 \& \mathrm{~d}=$ PALL\&RefSrch=yes \&Query $=$ PN/4015504. Accessed 9 Jul 2017

Rössner J (2013) Safety system for construction of a structure with a wooden component and structure produced using such a safety system. EPO EP2669879 (A2). https://worldwide.espacenet.com/ publicationDetails/biblio?FT $=$ D \&date $=20131204 \& D B=\&$ local $\mathrm{e}=\mathrm{en} \_\mathrm{EP} \& \mathrm{CC}=\mathrm{EP} \& \mathrm{NR}=2669879 \mathrm{~A} 2 \& \mathrm{KC}=\mathrm{A} 2 \& \mathrm{ND}=4$. Accessed 7 Jul 2017

Rybczynski W (2000) One good turn; a natural history of the screwdriver and the screw. Scribner Book Company, New York

Saman F, Gurong C (2003) Improvements relating to self-drilling screws. AU 760715 B2, filed September 6, 1999. Accessed 9 Jul 2017

Schulte H (1998) Cutting screw. EPO EP0831239 (B1), filed September 24,1996 . https://worldwide.espacenet.com/publicationDeta ils/biblio?FT $=$ D\&date $=19980325 \& \mathrm{DB}=\mathrm{EPODOC} \&$ locale $=$ en $\mathrm{EP} \& \mathrm{CC}=\mathrm{EP} \& \mathrm{NR}=0831239 \mathrm{~A} 1 \& \mathrm{KC}=\mathrm{A} 1 \& \mathrm{ND}=4$. Accessed $7 \mathrm{Jul}$ 2017

Semple KE, Xian D, Haghdan S, Smith GD (2014) Reinforced-core particleboard for improved screw-holding ability. Wood Fiber Sci 46(1):1-17

Shih S (2015) Anti-split wood screw. USPTO US 9145911, filed August 15, 2013. http://www.freepatentsonline.com/91459 11.html. Accessed 29 Sept 2015

Simon F, Simon F (2013) Device for securing the wooden handle in the eye of a hammer head and screw for attaching a wooden handle in the eye of a hammer head. EP2633959 (A2). https://worldwide. espacenet.com/publicationDetails/biblio?FT $=$ D\&date $=20130$ $904 \& \mathrm{DB}=\& 1$ oc al e $=$ en_EP \& CC=EP \& NR=26339 $59 \mathrm{~A} 2 \& \mathrm{KC}=\mathrm{A} 2 \& \mathrm{ND}=4$. Accessed $9 \mathrm{Jul} 2017$

Simons L (1989) Wood screw and method for making same. USPTO US 4815909, filed November 19, 1986. http://patft.uspto.gov/netac gi/nph-Parser?Sect $1=$ PTO2 $\&$ Sect $2=$ HITOFF $\& p=1 \& u=\% 2$ Fnet ahtml \%2FPTO \% 2Fsearch-bool.html\&r=1\&f=G\&l=50\& $\operatorname{co} 1=A N D \& d=P T X T \& s 1=4815909 . P N . \& O S=P N / 48159$ 09\&RS=PN/4815909. Accessed 9 Jul 2017

Sparkes WS (1987) Wood screw. USPTO US 4697969, filed September 6, 1985. http://patft.uspto.gov/netacgi/nph-Parser?Sect1 $=$ PTO $2 \&$ Sect $2=$ HITOFF $\& \mathrm{p}=1 \& \mathrm{u}=\% 2$ Fnetahtm $1 \% 2 \mathrm{FPTO}$ \%2Fsearch-bool.html\&r=1\&f=G\&l=50\&co1=AND\&d=PT XT\&s $1=4697969 . P N . \& O S=P N / 4697969 \& R S=P N / 4697969$. Accessed 7 Jul 2017

Su K-T, Su Y-J (2016) Wood screw. USPTO US9377045 B2, filed March 6, 2015. http://patft.uspto.gov/netacgi/nph-Parser?Sect1 $=$ PTO $2 \&$ Sect $2=$ HITOFF $\& \mathrm{p}=1 \& u=\% 2$ Fnetahtm $1 \% 2$ FPTO $\% 2$ Fsearch-bool.html\&r $=1 \& \mathrm{f}=\mathrm{G} \& \mathrm{l}=50 \& \mathrm{co} 1=\mathrm{AND} \& \mathrm{~d}=\mathrm{PT}$ XT\&s1 $=9377045 . P N . \& O S=P N / 9377045 \& R S=P N / 9377045$. Accessed 9 Jul 2017

Sydor M (2005) Właściwości konstrukcyjne półsztywnych kątowych połączeń płyt drewnopochodnych ze złączami/Constructional features of semirigid furniture corner joints with connections. Rozprawa doktorska/Ph.D. thesis, Poznań: Politechnika Poznańska. WMRiT. https://doi.org/10.13140/2.1.3231.7768

Sydor M (2011) Drewno w Budowie Maszyn: Historia Najważniejszego Tworzywa/wood in machine design: the story of most important material. Wydawnictwo Uniwersytetu Przyrodniczego w Poznaniu, Poznań

Sydor M (2017) Innowacyjność Mierzona Patentami Łączników Gwintowych Do Tworzyw Drzewnych/innovativeness measured by threaded fasteners for wood materials. Fastener. Rynek Elementów Złącznych (Dodatek Do STAL Metale \& Nowe Technologie), no. 1/2017 (March), pp 49-52

Sydor M, Wieloch G (2009) Construction properties of wood taken into consideration in engineering practice. Drewno 52(181):63-73 
Sydor M, Wołpiuk M (2016a) Analysis of resistance to axial withdrawal of screws embedded in locally reinforced MDF. Drewno 59(196):173-182. https://doi.org/10.12841/ wood.1644-3985.093.14

Sydor M, Wołpiuk M (2016b) The effect of pitch of thread on the force retaining screws in particleboard. Ann WULS SGGW For Wood Technol 96:151-156

Sydor M, Zmyślony G, Pinkowski G, Szymański W (2015) The influence of pitch on the holding power of screws in scots pine wood. Ann WULS SGGW For Wood Technol 90:193-197

Taneichi K (2013) Wood screw. USPTO US 20130195577, filed January 21, 2011. http://www.freepatentsonline.com/y2013/01955 77.html. Accessed 8 Jan 2013

Tankut N (2011) The influence of pilot hole on the moment resistance of screwed T-type furniture joints. Ann WULS SGGW For Wood Technol 73:75-84

Taşçioğlu C, Akçay C, Yalçin M, Şahin HI (2014) Effects of posttreatment with CA and CCA on screw withdrawal resistance of wood based composites. Wood Res 59(2):343-350

Terninko J, Zusman A, Zlotin B (1998) Systematic innovation: an introduction to TRIZ (theory of inventive problem solving). Taylor \& Francis Ltd/CRC Press, London

Ulryck M (2001) Vis A Bois Ou Analogue A Vissage Ameliore Et A Deux Entrees/Wood-screw or the like. FR 2786229 B1, filed November 19, 1999. lens.org/178-982-744-823-343. Accessed 7 Jul 2017

Vandenberg RA (2014) Fastener, installation tool and related method of use. CA 2725335 C, filed January 13, 2010. https://worldwide. espacenet.com/publicationDetails/biblio?CC $=$ CA\&NR $=27253$ $35 \mathrm{C} \& \mathrm{KC}=\mathrm{C} \& \mathrm{FT}=\mathrm{D}$. Accessed $7 \mathrm{Jul} 2017$

Walther U, Walther M, Walther T (2000) Screw for use as a fastener in fibrous material such as wood. USPTO US 6152666 A, filed March 16, 1999. http://patft.uspto.gov/netacgi/nph-Parser?Sect1 $=$ PTO $2 \&$ Sect $2=$ HITOFF $\& \mathrm{p}=1 \& \mathrm{u}=\% 2$ Fnetahtml $\% 2$ FPTO $\% 2$ Fsearch-bool.html\& $\mathrm{r}=1 \& \mathrm{f}=\mathrm{G} \& \mathrm{l}=50 \& \mathrm{co} 1=\mathrm{AND} \& \mathrm{~d}=\mathrm{PT}$
$\mathrm{XT} \& \mathrm{~s} 1=6152666 . \mathrm{PN} . \& \mathrm{OS}=\mathrm{PN} / 6152666 \& \mathrm{RS}=\mathrm{PN} / 6152666$. Accessed 7 Jul 2017

Wieland H (1998) Holztragwerkverbindungssystem/Drill screw. DPMA DE 29621923 U1, filed December 17, 1996. lens.org/018503-952-753-877. Accessed 7 Jul 2017

Wieland H (2000) Connecting screw for wood-concrete composite structure. EP0984177 (A2). https://worldwide.espacenet.com/ publicationDetails/biblio?FT $=\mathrm{D} \&$ date $=20000308 \& \mathrm{DB}=\&$ local $\mathrm{e}=\mathrm{en} \_\mathrm{EP} \& \mathrm{CC}=\mathrm{EP} \& \mathrm{NR}=0984177 \mathrm{~A} 2 \& \mathrm{KC}=\mathrm{A} 2 \& \mathrm{ND}=4$. Accessed 7 Jul 2017

Wieland H, Litze H (1998) Drill screw. EPO EP0849474 (A1). https://worldwide.espacenet.com/publicationDeta ils $/$ biblio?FT $=$ D\&date $=19980624 \& D B=\&$ locale e $=$ en $\mathrm{EP} \& \mathrm{CC}=\mathrm{EP} \& \mathrm{NR}=0849474 \mathrm{~A} 1 \& \mathrm{KC}=\mathrm{A} 1 \& \mathrm{ND}=4$. Accessed 24 Jun 1998

Wills ES (1872) Improvements in wood screws. USPTO US 126366 A. lens.org/047-155-216-095-742. Accessed 7 Jul 2017

Wołpiuk M, Pohl P (2009) investigations on the effect of a polyurethane preparation on the holding capacity of screw connectors mounted in a dry-formed MDF board. Ann Warsaw Univ Life Sci SGGW For Wood Technol 69:450-455

Wołpiuk M, Sydor M (2016) Practical screw withdrawal strength in chosen wood-based composites. Ann WULS SGGW For Wood Technol 96:310-314

Yoon J, Park H, Kim K (2013) Identifying technological competition trends for R\&D planning using dynamic patent maps: SAObased content analysis. Scientometrics 94(1):1-19. https://doi. org/10.1007/s11192-012-0830-6

Publisher's Note Springer Nature remains neutral with regard to jurisdictional claims in published maps and institutional affiliations. 